Portland State University

PDXScholar

6-16-2021

\title{
Our Peer the Pigeon: Impacts of the COVID-19 "Anthropause" on PSU Campus Urban Foragers
}

Audrey Douglass

Portland State University

Follow this and additional works at: https://pdxscholar.library.pdx.edu/honorstheses

Part of the Other Animal Sciences Commons, and the Population Biology Commons Let us know how access to this document benefits you.

\section{Recommended Citation}

Douglass, Audrey, "Our Peer the Pigeon: Impacts of the COVID-19 "Anthropause" on PSU Campus Urban Foragers" (2021). University Honors Theses. Paper 1058.

https://doi.org/10.15760/honors.1084

This Thesis is brought to you for free and open access. It has been accepted for inclusion in University Honors Theses by an authorized administrator of PDXScholar. Please contact us if we can make this document more accessible: pdxscholar@pdx.edu. 


\section{Our Peer the Pigeon}

Impacts of the COVID-19 "anthropause" on PSU campus urban foragers.

by

Audrey Douglass

An undergraduate honors thesis submitted in partial fulfillment of the requirements of the degree of the Bachelors of the Sciences

in

University Honors

and

Environmental Studies

Thesis Adviser

Alida Cantor

Portland State University 
Abstract:

The 2020 COVID Pandemic presented a paradigm shift dubbed, by some scholars, the 'Anthropause,' an ecological epoch in which human-environment relations shifted. As was the case for many urban species that depend on the foraging of food waste, this meant a fundamental disruption to their food systems and to the entire urban eco-web. The Portland State University campus, an urban campus containing urban green space, presents a unique opportunity to observe animal behavior, while also a succinct microcosm to study food waste flow changes, and compare species layout to other urban parks in the Portland, Oregon Metro area. Decreased food waste output from proximal restaurants, businesses, residences, and campus dining establishments may have led to food web shifts observed in other cities. This thesis finds that inner-city green spaces and anthropophilic species are often excluded from supply chain investigations into food waste, and are also often ignored by ecological studies of urban species. Campus green space provides an excellent opportunity for the study of urban foragers in proximity to humans, and human perception of those very foragers. 


\section{Introduction}

"Anthropause" is the newly proposed term to encapsulate the new landscape many species now navigate- one which has, since the inception of the COVID-19 pandemic, experienced a shift or diminishment in human presence. In light of these current events, the conversation around urban foragers has been one primarily focused on, as is understandable during times of pandemic, their potential to be zoonotic disease vectors to urban citizens. However, one element much less underscored is the altered ecosystem dynamics our cities now present, and how this impacts the anthropophilic species who have evolved alongside us to thrive in them. One of the main harbingers of this shift is the change in edible food waste output. The campus ecosystem of Portland State University (PSU), an urban campus in downtown Portland, Oregon, USA, presents a unique urban greenspace, one which is transiently occupied by high flows of students, who bring with them food waste input from a myriad of source- nearby restaurants, coffee shops, on campus cafeteria dining, vending machines, food carts, the Saturday Farmer Market at PSU, and seven widely distributed dumpsters which contain refuse from all the above. The situation is such that it may indeed be easier to find areas without potential food for a foraging species. These urban foragers are overwhelmingly members of four species- Corvus brachyrhynchos (crow), Sciurus carolinensis (grey squirrel), Rattus norvegicus (Norweigan rat) and Columba livia (common pigeon). These species are notable in Portland for the attention they've drawn, with management solutions and plans put in place for nearly all of them, and for their success as urban species. Additionally, many have garnered attention in the news and media- to Portlanders, and to the broad PSU community, these are no general foragers, but the species of our city. The COVID-19 lockdown fundamentally changed on-campus life, and by extension, theirs. 
In this thesis, the PSU campus will be examined alongside similar urban greenspaces with a high human proximity for species heterogeneity. This paper will contextualize urban ecosystem species dynamics that inevitably play into the PSU campus ecosystem, such as trophic cycling, zoonotic disease potential, and the negative health implications of a human diet on animal health and sedentariness. Through the framework of animal geographies, the portrayal and public perception of these forager species will be examined for pre-and post-COVID-19 sentiments, to see if this decrease in edible food waste during the pandemic, and subsequent change in foraging habits, can be linked to a change in media portrayal. I am especially interested in tracking differing portrayals that are historically rooted (Biehler, 2013) as well as a focus on available species data.

\subsection{Research Questions}

How has the pandemic affected the existing network of waste-foraging animals in the PSU campus area? Has the public perception of forager species changed since classes transitioned online? How did the pandemic affect the lives of PSU's urban foragers, and what does available data suggest about the current place of urban forager species in the sciences?

\section{Literature Review}

The field of Urban Ecology distinguishes aspects of urban species: they are noted for displaying high density with low diversity among species such as birds (Faeth, 2005) This study notes that the urban environment is one that can be characterized by high spatial heterogeneity as well as fragmentation of micro-habitats (Lepczyk, 2018). What would be the implications of studying such dynamics in the microcosm of a college campus, which is in all reality a fragmented habitat within a fragmented habitat? 
Another aspect this research touches on is resource cycling (Crombach, 2009), as urban species break down our litter and recycle energy through the system. This is a common thread to urban species, whether they seek out our cities for warmth or roost: the uniting factor is they are all there to partake in human excess (food, heat, etc.). Within urban ecology research, previous work has focused on urban species as a disease vector (O'Connor, 2010), their adaptations to the city ecosystem (Partecke,2007; Gibbs, 2019) and, in some specific cases, the philosophical and psychological place or urban species such as the 'pigeon paradox', (Ma, 2015; Dunn, 2016). The pigeon paradox is a conjecture resting on three points: that an increasing number of species are going extinct, and that more people than ever before are living in cities - so it follows that the natural world they do come into contact with is likely that of urban nature. The third aspect, relating to the pigeon title, is the idea that urban species, pigeons nonexempt, can serve as an umbilical cord to nature for city dwellers and provide an impetus for global conservation. . Decker's (2000) framework of 'Energy and Material Flow Through the Urban Ecosystem' provides the groundwork from which my analysis will sprout. This framework states that material flow in a megacity can be likened to biological metabolism, and emphasizes how the resource metabolism of utilities such as trash could be 'cross pollinated' by the urban ecosystem. Additionally, one branch of urban ecology research has investigated how the human-waste diet has had a detrimental effect on animal health (Newsome,. 2017). For better or worse, they are species that parallel us, and as anthropophilic species, they are intimately tied to our lives, and our trash. I will be extending this framework of biological waste metabolism in the city, establishing what amount of edible food waste is available to urban species as a tributary of our own meals, and use broader trends of food waste to account for pre/post pandemic edible waste available to urban foragers. Important methodologies and concepts I will be using to construct 
my argument will be that of trophic cycling and habitat fragmentation. I will also be building off Alberti's concept of ecosystem resilience in regards to the urban ecosystem (Alberti, 2004)

In addition to understanding ecological dimensions of urban nonhuman species, another body of research examines discourses, perceptions, and understandings of urban wildlife (Davies, 2004). Much of the discourse focusing on urban species measures their value in accordance with human sensibilities (Collard, 2017). The niche of urban species within the city as disease vectors, their existence as an aesthetic oasis of nature among the urban, or their foraging habits are also of interest to many, as previously noted through the pigeon paradox.

Studies that have tried to estimate the change in urban waste due to the COVID-19 pandemic have so far not accounted for the species so intimately tied to food waste-urban foragers. We lack a proper understanding of the urban species' role in a college campus ecosystem, as well as the effect the pandemic may have had on these species. Work in urban ecology is by necessity interdisciplinary- it ties together conceptual models of resource flows into cities, sociological implications of human behavior, the data collection of parasitic samples, and the tallying of urban species, to name a few. In this thesis, I add to this area of research by analyzing the changes in urban food waste metabolism in one micro-system (Downtown Portland) and applying this information to urban foragers after the COVID-19 pandemic.

\section{Methods}

Studying urban metabolism shift, in the context of urban species post-pandemic, requires a mixed methodology approach (Schoonenboom, 2017). Due to both the relative novelty of this 
pandemic, and the limited availability of data, my methods include field observation, Urban Wildlife Information Network (UWIN) data, supply chain analysis of food waste globally, food waste in Portland specifically, and media articles. In this study I triangulate between these multiple data sets and draw from multiple sources.

The Urban Wildlife Information Network diligently collects data on urban species in many cities using bait-camera traps, in an effort to better understand urban species, in a world that is increasingly urban. Their cameras use a motion-triggered apparatus to photograph passing species- and sometimes this is homo-sapien. Due to the nature of the camera traps, the logistics of setting up cameras where they wouldn't be stolen, and greenspace size, there were not any camera traps set up in the park block areas. However, I was able to infer what species might have been photographed downtown by comparing the species distribution in several parks UWIN had set up cameras. I then inferred a 'spectrum' of human presence by how large a percentage of human capture was recorded. This gave me two sites, Johnson Creek Park and Tokola wetlands, which had the highest percentage of human activity, compared to three other urban parks with varying degrees of humans. My logic was that the sites with higher human activity would be more comparable to the downtown ecological landscape.

I also identified major vectors of food waste in the campus area, using the 2017 Oregon Residential Food Waste Study. Their study showed that edible food was found to represent $49.1 \%$ of the food disposed of at curbside compost bins- of which 53 of the 58 bins were at urban collection sites. I also examined previous campus sustainability audits of the cafeteria and metrics on waste generation from the Saturday PSU Farmers Market. Using these metrics I extrapolated the trash output of the PSU campus. Because data collection ceased after the pandemic, global food waste trends globally were inferred onto the campus area using results 
from several studies on the impact of the pandemic on food waste (Jribi , 2020, Ellison, 2020, Roe, 2021).

Finally, since urban campus green space is unique, I conducted observational field work investigating the behavior of my four species. I compare these observations to scholarly literature to infer how changes in these flows may have affected the life of campus foragers, and compare this to changed public sentiments of urban foragers since the inception of the pandemic. I use this information to detail a prospective future of urban species using historical perspectives on the species and what our joint campus ecosystem may look like, going into the future (Biehler, 2013).

\section{Results and analysis}

\subsection{Estimating food waste in PSU campus area}

In order to estimate the amount of food waste that might end up in dumpsters and trash cans around the park blocks, data first had to be assembled on the existing edible food waste being created by primarily restaurants and residences downtown, with further appreciation to campus trash flows from the dining hall. A Metro study concluded that residents and businesses in the greater Portland area throw away 1.3 million tons of garbage each year, with about an even split between business and residents as a whole. Nearly a fifth of that refuse itself is food waste. (Oregon Metro Food Scraps Policy: Commercial Food Scraps Composition Study, 2020) I calculated food waste based on $1 / 5$ of half of 1.3 million tons, giving a rough estimate that 130 thousand tons of food waste were being thrown away from businesses like the restaurant and 
hotel industry in Portland. About 28,000 tons of food scraps from that overall food waste were collected from businesses around the Portland region in this 2016 review for compost processing. Of the waste from the PSU Campus specifically, it is difficult to estimate food waste output from strictly park block trash cans, as the Parks are technically under jurisdiction of the city of Portland, and many non-student denizens utilize campus trash cans. A sustainability audit of the cafeteria by the Student Sustainability Center found that in just one week of programming (two hours daily, 8 hours total), $204.6 \mathrm{lbs}$ of food waste was produced. Accounting for the 33 three full week terms that constitute the fall, winter, and spring semesters in which the dining hall operates full-time, there would be around $6751.8 \mathrm{lbs}$ of food waste from the dining hall a year, conservatively. This number excludes food waste produced from the other dining locations on campus, food carts, and residential waste from the dorm room buildings. Initially all campus meal services and dining were shuttered at the beginning of the pandemic, slowly opening essential dining for the few students who remained living in on-campus housing, so this number of $6751.8 \mathrm{lbs}$ represents the typical waste outflow which was lost, at least for the first few months of the pandemic.

Another food-waste generating producer in the park blocks that shouldn't be discounted is the Portland Farmers Market. A typical Saturday at the Farmers Market generates more than sixty 45-gallon garbage bags loaded with food scraps, plastic water bottles, disposable coffee cups, paper plates, packaging and other discarded items. 8.34 times 45 x $60=22518$ lbs x 52 Saturdays a year $=1170936 \mathrm{lbs}$, or 585.468 tons of food waste. Because the Farmers Market never formally shut down operations downtown, opting instead to distance tents and erect hand-washing stations, we can assume for the purposes of this food-waste analysis that while the crowds may 
have been sparser, the PFM contributed the same proportion of food waste to the campus park blocks.

\subsection{Understanding global pandemic food trends}

A study on the impact of COVID-19 on food waste (B.E Roe, 2021) found that food acquisition patterns in consumers were fundamentally changed by the pandemic, especially when compared to pre-COVID numbers (Restrepo, Rabbit, and Gregory 2020). Total consumer spending at restaurants and hotels declined by more than $60 \%$ after the announcement of a global pandemic. Extrapolating these trends to Portland would align with the more than 130 restaurants which have closed since the inception of the pandemic last March.

A survey of consumers from around the UK in April of 2020 (WRAP 2020) using food-waste tracking journals in relation to yearly consumer waste of the staple food items found that food waste trends did change during the pandemic. Among these foods were common edible food waste items such as bread, milk, chicken, and potatoes. They found that in the months after the pandemic, consumers responded that their food waste declined from $24 \%$ to $14 \%$ from the previous year. If these trends were applied to urban residents around the park blocks, this diminished flow of food waste would result in another avenue of empty bins for urban foraging species.

Using this data and the data discussed in section 4.1, I determined the approximate change in food waste between pre-pandemic and pandemic times, and found that food waste scraps available to urban foragers decreased significantly (Figures 1 and 2). 
Figure 1: A table of compiled food waste data in Portland during the 2019 year and 2020, showing the change in Total Food Waste (TFW)

\begin{tabular}{|l|r|r|}
\hline & Portland & \\
\hline Year & $\mathbf{2 0 1 6}$ & $\mathbf{2 0 2 0}$ \\
\hline Businesses & $260000000 \mathrm{lbs}$ & $156000000 \mathrm{lbs}$ \\
\hline PSU Dining Hall & $6751.8 \mathrm{lbs}$ & 0 \\
\hline $\begin{array}{l}\text { Portland Farmers } \\
\text { Market }\end{array}$ & $1170936 \mathrm{lbss}$ & $1170936 \mathrm{lbs}$ \\
\hline $\begin{array}{l}\text { Food Scraps collected } \\
\text { by METRO }\end{array}$ & $56000000 \mathrm{lbs}$ & 0 \\
\hline Total Food Waste & $317177687.8 \mathrm{lbs} \mathrm{s}$ & $157170936 \mathrm{lbs}$ \\
\hline
\end{tabular}

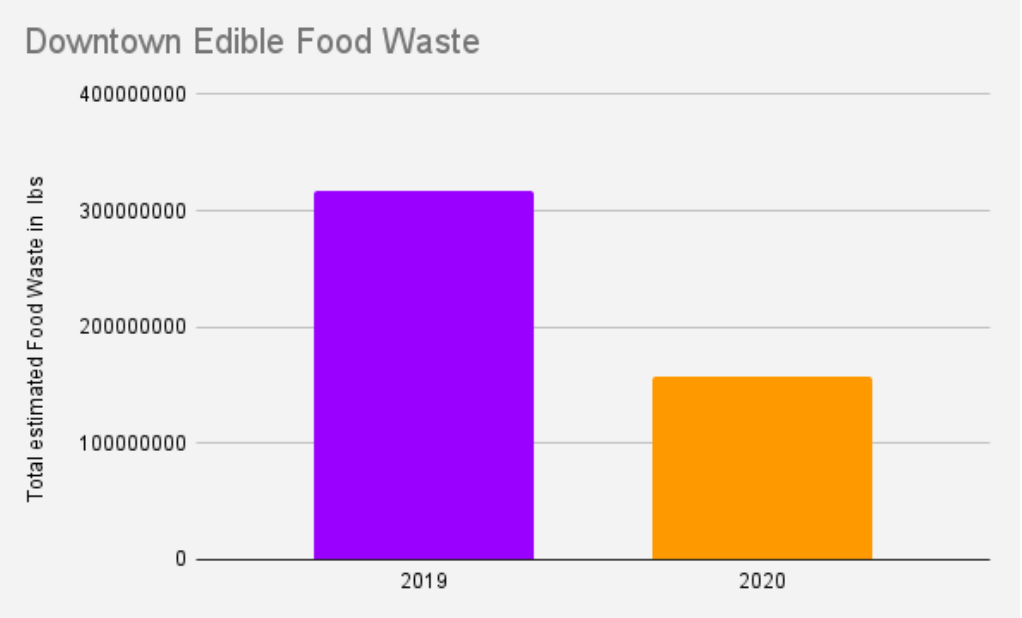

Figure 2: The above graph demonstrates the total change of TFW from 2019 to 2020.

\subsection{Understanding urban wildlife through remote camera observation}

The Urban Wildlife Information Network (UWIN) diligently collects data on urban species using camera traps, in an effort to better understand urban species, in an increasingly urban world. Collaboration with their Portland members yielded pre-pandemic data for several urban greenspaces in the METRO area. I chose several sites to examine for this paper. Two urban parks were selected (Johnson Creek Park and Tokola Wetland) based on their proportionally high proclivity for human activity to register on camera, as well as their location in proximity to residential developments in urban areas. Various species of squirrels, which accounted for an 
appreciable number of pictured events, were combined into one category. It should also be noted that Johnson Creek represents an urban park closer to a small waterway, and thus might harbor species like raccoons. The data suggests a decreased species diversity in areas with more human activity. Johnson Creek Park (Figure 3) and Tokola Wetlands Park (Figure 4) both have at least a third of their photos identified as human, which speaks not only to camera placement (many cameras were placed in trees and off-ground) but also to the relative presence of people in both areas. As such, this pre-pandemic spring data will serve as comparative parks to the urban campus area.

Figure 3: Makeup of species captured by camera trap photographs, Johnson Creek Park

\section{Johnson Creek Park (Urban)}

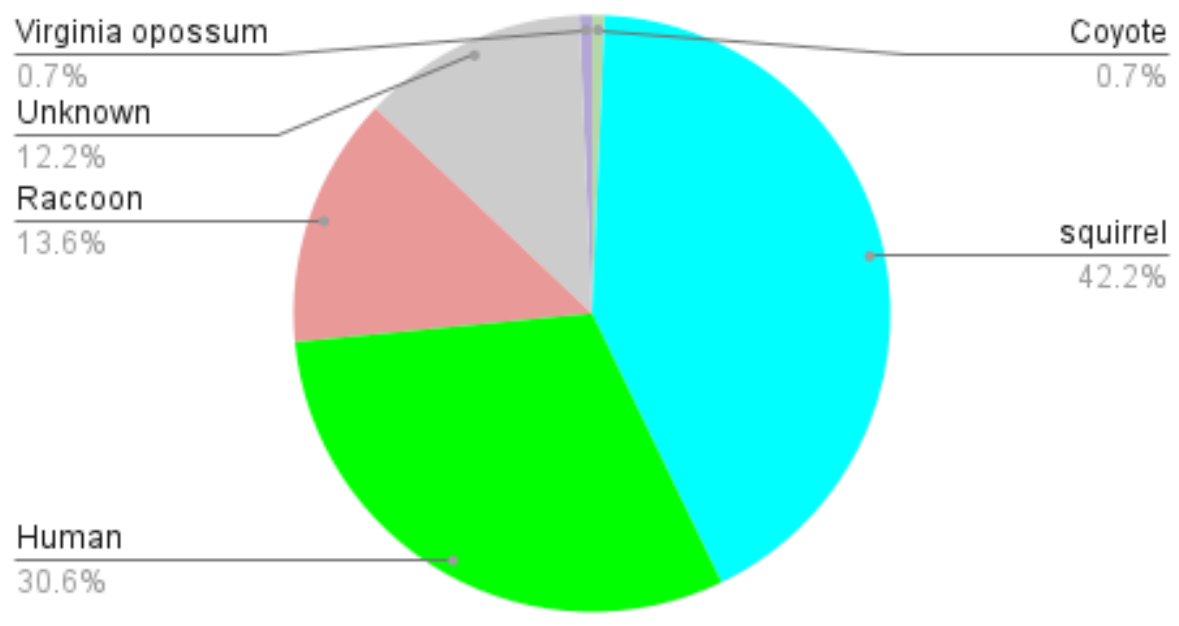


Figure 4: Makeup of species captured by camera trap photographs, Tokola Wetlands Park

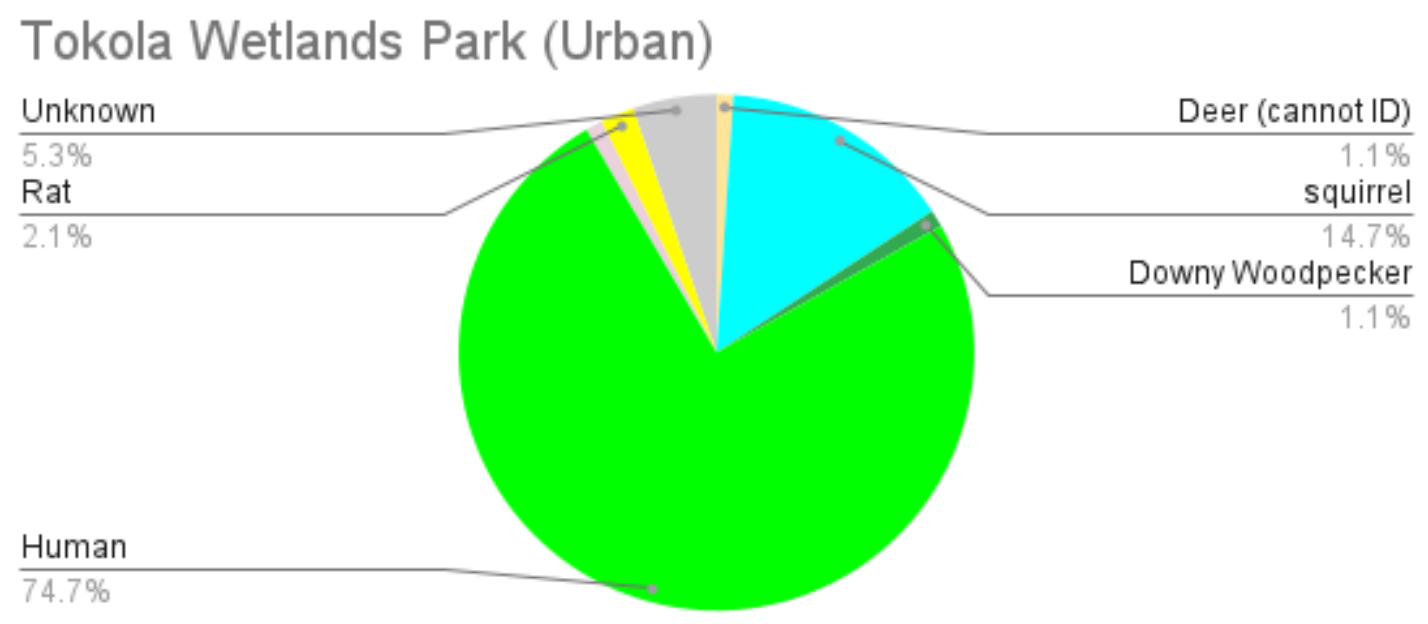

I also examined several other UWIN sites, including the Jenne Butte Park (Figure 5) and Beggars Tick Wildlife Park (Figure 6), which are both located East of the 'Urban' designated parks, with appreciably less human activity noted by the motion-triggered cameras. At least 7 species (humans aside) were noted in these parks, even though Tideman Johnson Park (Figure 7), our third data point, sits only blocks away from Johnson Creek, indeed, both along stretches of Johnson Creek. The difference seems to be that the smaller Johnson Creek Park is buffered on three sides by the residential and commercial neighborhood of Sellwood, while Tideman lies nearby to adjoining greenspace through the Westmoreland Nature Park, Eastmoreland Golf Course, and Crystal Springs Rhododendron Garden. Johnson Creek therefore better serves the purposes of direct comparison, as it represents a smaller urban greenspace, transected by walking paths, and encircled by development.

Figure 5: Makeup of species captured by camera trap photographs, Jenne Butte Park 


\section{Jenne Butte Park (rural Gresham)}

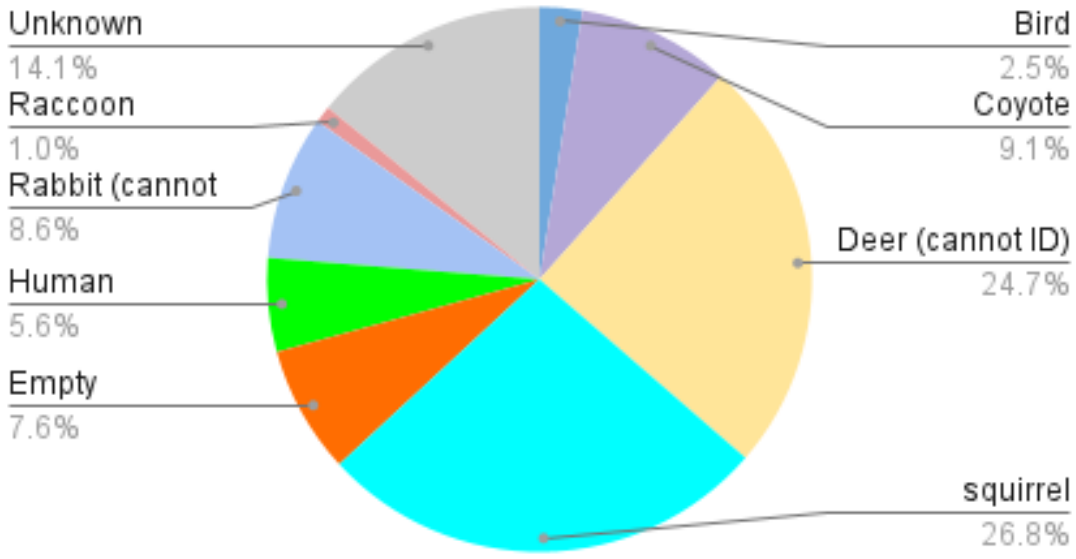

Figure 6: Makeup of species captured by camera trap photographs, Beggars Tick Wildlife Refuge

\section{Beggars Tick Wildlife Refuge}

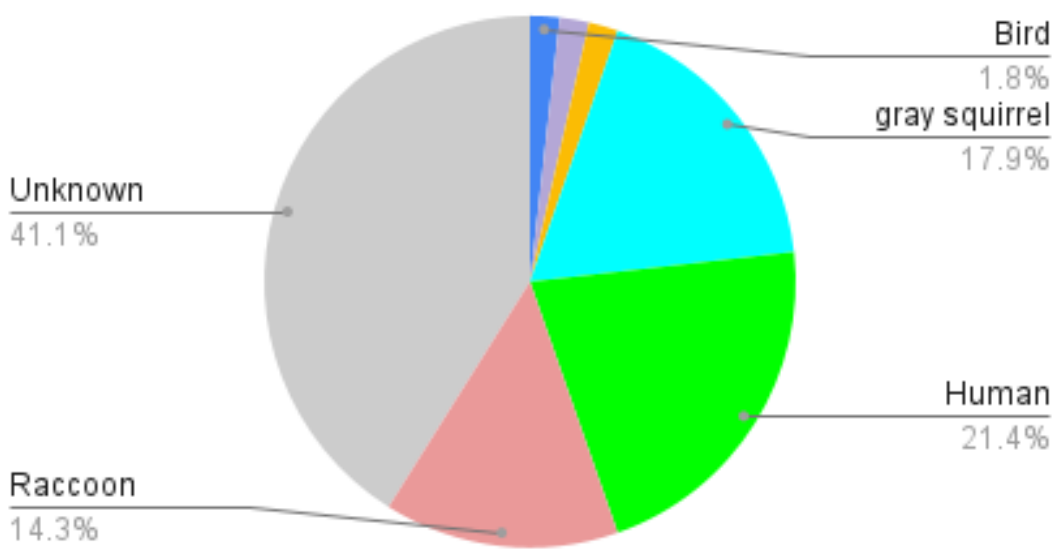

Figure 7: Makeup of species captured by camera trap photographs, Tideman Johnson Park 


\section{Tideman Johnson Park}

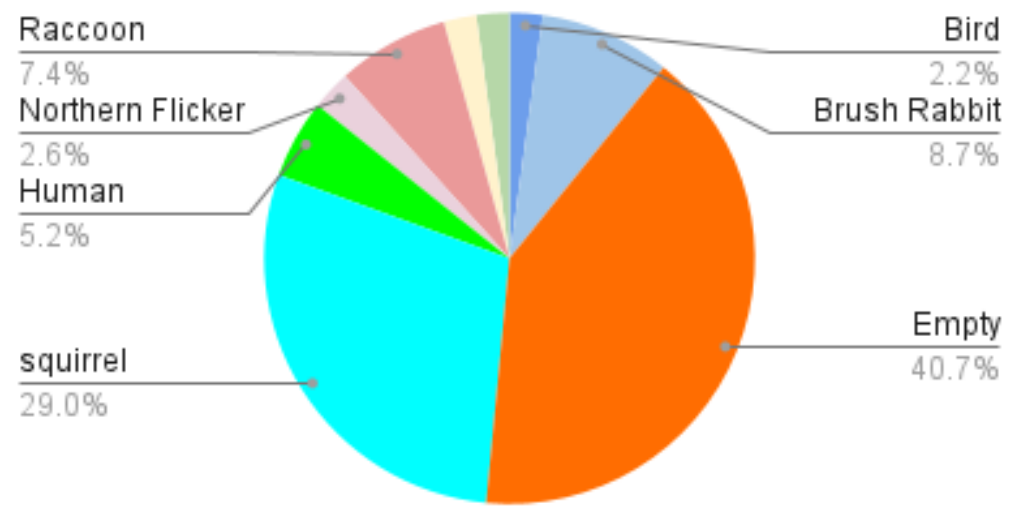

These rural sites showed a greater species distribution, which may have also been tied to their relatively larger size as urban greenspaces.

To understand how these species distributions compare to population density, I mapped the five sites over a population density map of Portland (Figure 8). As can be seen, none of these sites are in the park blocks area. The population density map was compiled from two shape files from METRO's open-sourced rlis discovery data sets. These were the 2010 US Census Block Groups, and the April 28, 2021 American Community Survey of 5-year population estimates.

Figure 8: Map of UWIN cameras described above, along with population density.

This map is a projection of the Urban Parks of the Portland area, with a 1)Tokola Wetland 2) Jenne Butte Park 3) Johnson Creek Park 4) Tideman Johnson 5) Beggars Tick Wildlife Refuge. This lighter yellow area designates the urban core-downtown Portland, with some appreciably high population density, while darker values are assigned to less-populated areas. The density component is a composite of both the 2010 US Census Block Groups, 2021 American Community Survey of 5-year population estimates. 


\section{Urban Parks of the Portland Area}

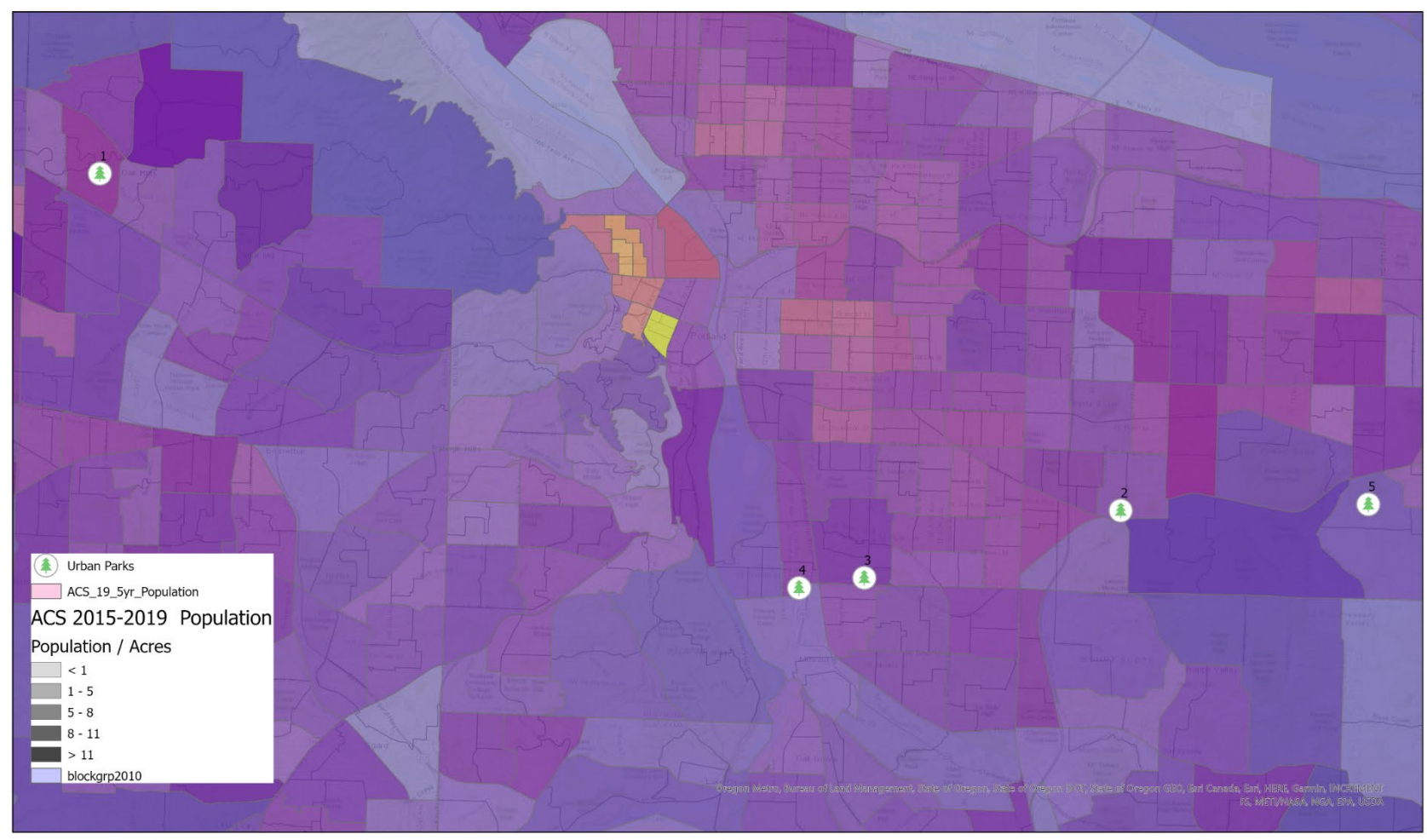

Figure 9 shows the species distribution in combination with the population density map. As a category, different species of squirrel were combined for analysis purposes (bright blue in pie chart). The two human-abundant parks are, animal-wise, squirrel dominant, but the squirrel population was also high in Beggar Tick, Jenne Butte, and Tideman Johnson Park. There is also a sizable racoon population at two of the parks, Johnson Creek and Beggars Tick, but this can be explained by their location near a marsh area, and this is not the case for downtown Portland. In two of the parks with the lowest human density, Tideman Johnson and Jeanne Butte, coyotes and an assortment of birds were observed in the camera traps, which is wonderful news on the front of data collection. Based on the data from these multiple sites, I would expect PSU's park blocks to be most like Tokola Wetland, because of the high propensity for human activity, as well as the lack of racoon population a wetland-containing park such as Johnson Creek might 
reflect. Similarly, Tokola Wetlands Park also hosted one of the only captured rat appearances, as well as a woodpecker. However, I do not believe the deer population, however small, would carry over to the immediate park blocks area, such it is very probable that these parks cannot truly reflect the urban life of a park situated closer to an even higher population density, as can be observed below. I would expect to see squirrel life downtown, as the cameras proved quite adept at capturing squirrel life. Their rigging to trees may have contributed, as very few lowlying ground cameras were installed in the other parks, as well, so species such as rats may have been harder to capture. I would also expect pigeons and crows to have been captured in the cameras as well, and in my conclusions will later discuss the potential use of food waste locations as bait in of themselves for urban species.

Figure 9. Urban Parks of Portland with South Park Blocks (PSU Campus) highlighted in green, with species population pie charts superimposed beside their respective park. A legend on the left assigns each species a color, while a legend in the lower left-hand corner of the map show which icon designates urban parks, as well as the two censuses used to construct the Portland density map.

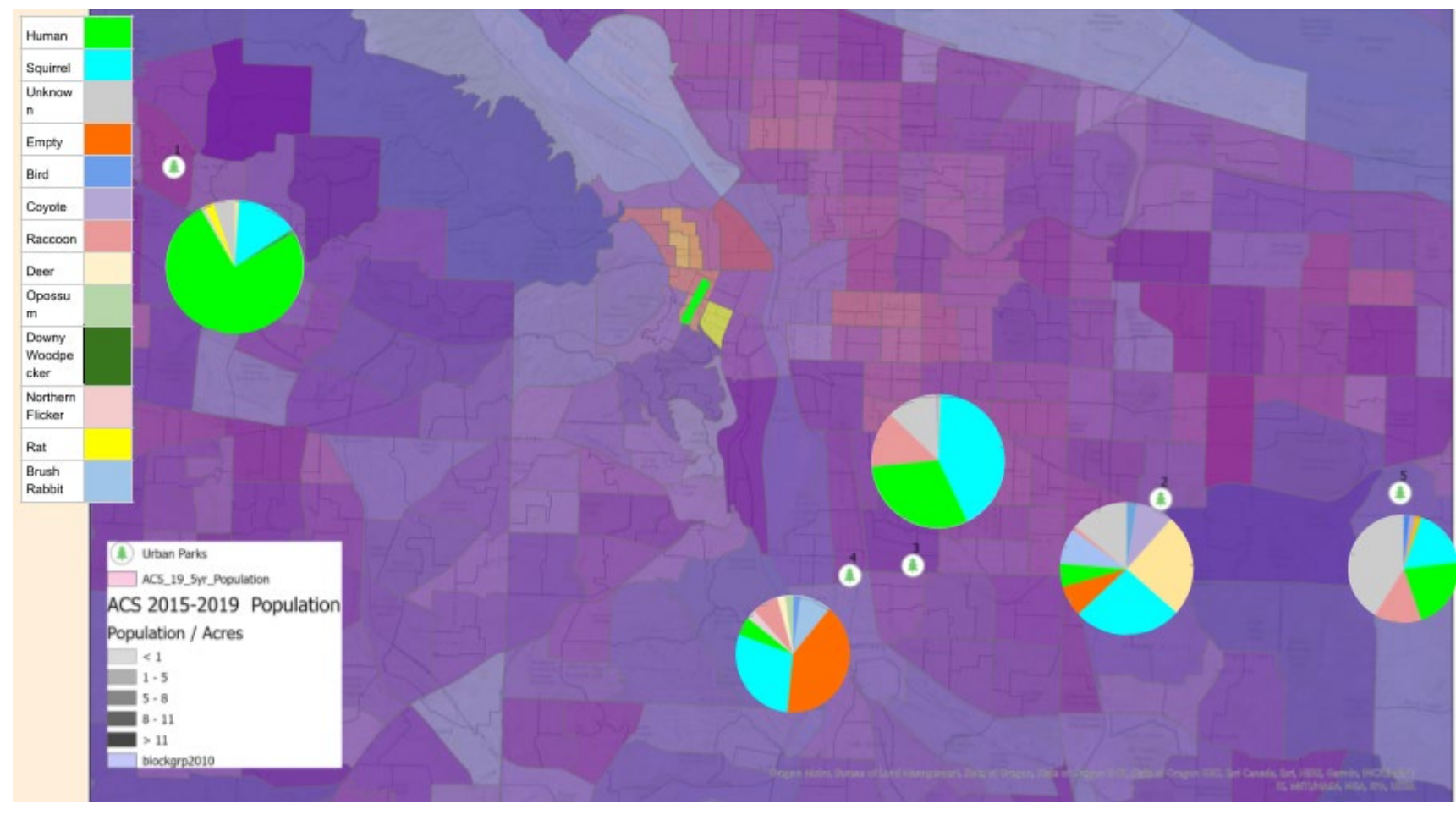




\subsection{Field observations of urban wildlife at PSU}

Forays into the urban campus area were undertaken this spring, for the purpose of collecting field notes on urban foraging behavior. Notes were taken while walking an organic route of the campus park blocks, with pause to examine the 7 existing PSU dumpster locations to consider foraging behavior. Squirrels, crows, and pigeons were observed, as well as the typical canine and human life-forms which make up the urban ecosystem. Rats were absent, however, potentially due to their nocturnal foraging pattern. Of note were two instances of people actively feeding both a squirrel and a pigeon. A crow was found perched on a bubbler fountain near the Simon Benson House with a wedge of bread in its mouth. Further down, a pigeon was noted pecking at peanuts scattered on the grass in the PSU campus park blocks (Figure 10). There was little reluctance observed in animals courting humans with food, and they had a large tolerance for human approach, especially when food was in the equation. The formerly mentioned squirrel was being nonchalantly hand-fed by a couple relaxing in the park-blocks. The only indications of real change on campus were the masks being worn, the diminished student presence, and the absence of food carts. 
Figure 10: Pigeons foraging for food in the PSU campus park blocks.

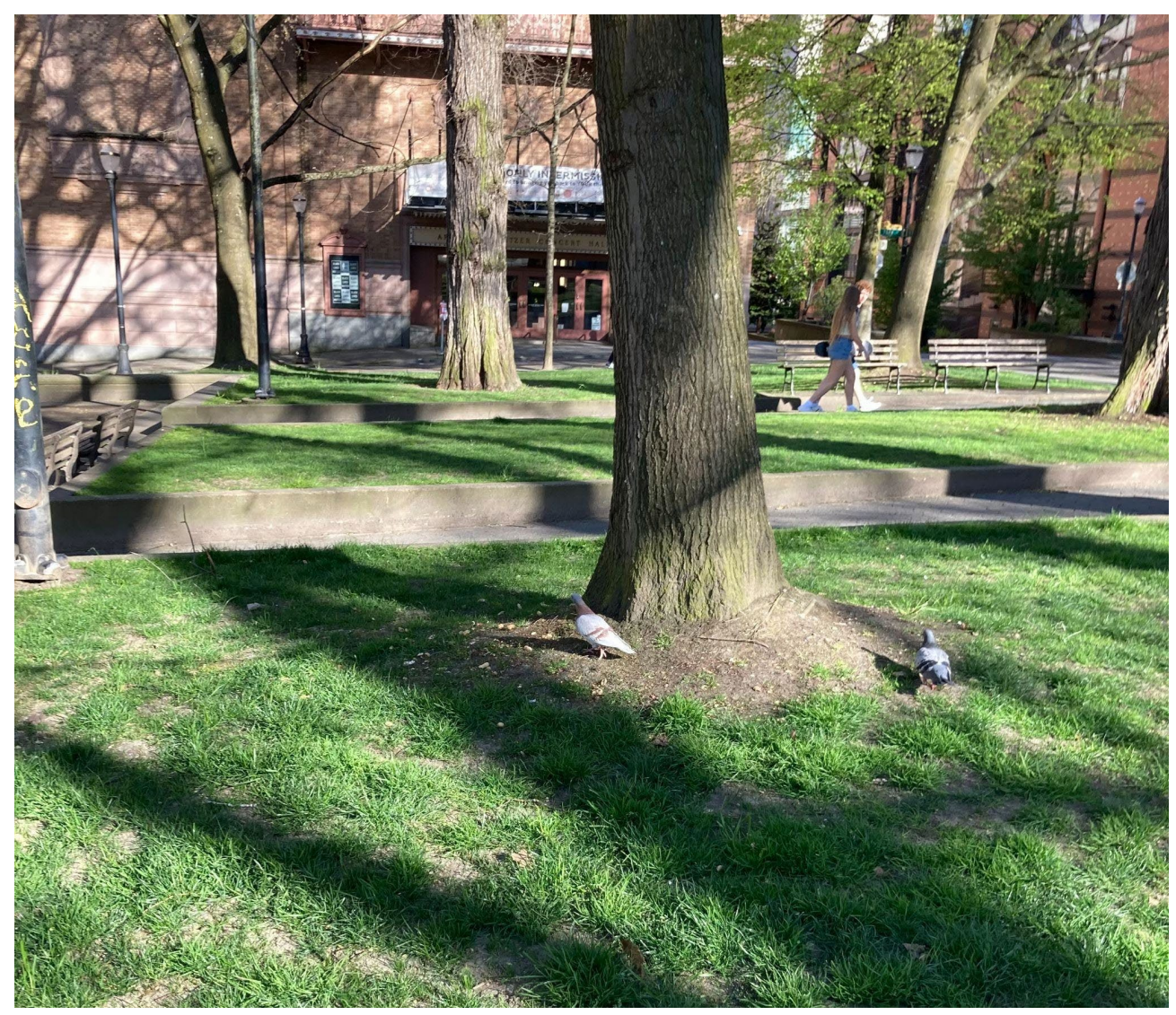

The low diversity noted in the parks with a typically high human presence can be correlated with

the low species diversity observed in the park blocks- a predominance of squirrels, pigeons, crows, and the ever-elusive rat.

\subsection{Media Analysis}

One New Orleans publication noted a growing residential rat problem, and outlined a poisonbaiting plan, finding, as Chad Calder puts it in "Rats ranging more widely out of hunger."

"With many restaurants closed, rats accustomed to getting food out of public view are having to forage more widely, and empty streets lined with residential garbage cans are the next closest source."

As if in response, a New York Times article from May of 2020 notes that the few restaurants that 
remained open saw a mass influx of rats (Padilla 2020). Animal welfare groups such as the Bonn-based German Animal Welfare Association headed by Leonie Weltgen put out statements warning that their city's pigeon-population, loyal to its downtown food source, was at risk of slow starvation as a consequence of the COVID lockdown. City centers empty of their people are not empty of the species who rely on human crumbs.

Another peculiar media finding was that many people across the country have been 'rescuing' baby squirrels in record numbers, presumably because they are quarantined at home, as was described in the articles 'Wildlife Rehabilitators Are Overwhelmed During the Pandemic' (Dickens, 2020) and 'Shutdown means fewer dead possums, more baby squirrels at rescue center' (Schroeder, 2020).

People also fed squirrels recreationally and wrote op-ed pieces on connecting with squirrels during the long weeks at home, for example, "How a Sickly Squirrel Offered Me Unexpected Comfort." (Spritzer, 2021). Rats, however, got not nearly so much sympathy and as the above quotes suggest, people were horrified to see them out and about during the day. Rats may also have become predated by hungry crows and seagulls, who are also food scrap scavengers struggling to survive in the pandemic. This predation was observed in Europe in the article 'Rome's seagulls hunt rats and pigeons as lockdown starves them of scraps' (Ng, 2020). As an interpretation of these findings, it would seem select urban species were vying for remaining food available, predating each other when the situation was dire enough (crows to rat) and, as a CDC headline gruesomely put it, another outcome was cannibalistic rats, described in the article ' $C D C$ warns of aggressive cannibal rats facing shortage of garbage to eat' (Helmore, 2020). 


\section{Conclusions}

\subsection{Understanding pandemic-related shifts for urban species}

What can we understand from this data, and what can't we? If one thing is for certain, it is that the food landscape for species in urban Portland has drastically shifted since the pandemic. Portland Food and Drink has tallied 131 permanent restaurant closures since the pandemic, with many of these establishments in and around the urban nucleus of the PSU Park Blocks. With the steady stream of student and faculty clientele gone, many of the businesses downtown have had to shutter their doors- and their dumpsters. Based on the food waste analysis, there was a $51 \%$ decrease in food waste in the Portland area, with a substantial decrease specifically in food waste exiting the student dining hall, and presumably the dorm buildings- meaning a significant downstream impact on foraging species. This decrease in food waste output was echoed in residents and businesses of other cities, as restaurants had to fundamentally shift operations, and consumers themselves generated less edible waste. This puts the species used to scavenging off edible restaurant food waste in dire straits, as they attempt to navigate a drastically shifting ecosystem. Their circumstance is corroborated by both national and international media sources finding an increase in day-time rat activity and aggression as they searched for food scraps.

As rats and other species lose their established food sources, in this case, the specific dumpster and trash-cans their colony is loyal $t$, they are forced to range more widely for food. Portland has had a long history of, as The Atlantic calls it in "How Portland Lives With, Not Against, Its Rats," 'artisanal' methods of pest-control which have historically kept both rat population and density low in the Pacific Northwest city. For residents that meant adhering to a 19th century ordinance of tight-fitting lids snug on rat-proof garbage cans. Trash-bags were noted to be the 
true culprit of booming rat populations, as they tear easily, spilling their contents of edible waste. And in Portland, those trash bags are predominantly located in the Downtown sphere inside of open cans, or tossed into dumpsters whose lids may lay open.

In Portland, when we account for the estimated 51\% decrease to the downtown food waste, taking into consideration consumer spending shifts away from restaurants, and massive outflux of the student body at PSU, the scene was set: Massive food shortages for urban foragers. March of 2020 constituted a massive shift in food circumstance for the species of the city park block. While the downtown animal population seems to have grown unabashed to human presence, it is equally reliant on humans as a food pipeline. My own observations noted squirrels being handfed, and pigeons pecking at the scraps of peanuts which had been tossed onto the park block grass. This reliance is, in some cases, not simply one of scavenging- in some cases we actively feed urban species, as in the park blocks, and I believe this hints at, in some form, our affinity for them.

Many urban cities have struggled with too-high numbers of pigeons, and particularly for Portland, a robust crow roost, but a circumstantial culling of their numbers through starvation isn't proper species management. These species stoke species diversity in a playground we've created solely for human benefit, and indeed, provide humans surrounded by high-rises with bird calls, and a flurry of squirrel pursuit.

\subsection{Limitations and what we can't know}

There were no UWIN cameras directly placed within the PSU park blocks, making it harder to understand exactly what urban species are present in this area. The lack of UWIN data for forager species in the PSU park block areas is several-fold- by strict definition of urban green 
space, the campus blocks do not constitute a large enough area to be considered a green space in the UWIN framework. Adding to this, cameras must be placed strategically to avoid damage of theft, and therefore there is a lack of ground-based motion-triggered cameras. As a result, camera placement might be incumbent on the detection of species foraging low to the ground, such as rats, and to birds foraging for food scraps, which often lay littered on the sidewalk. This makes collection of multiple-urban species data, such as through a motion-trigger format, more difficult, as their ecosystem is the human public sphere. Additionally, there were limitations in calculating the exact waste flow in and out of the park blocks area, as well as how much food waste was actually being consumed by urban species. Future study would be invaluable as to determining the average consumption of food waste for an individual of each species.

\subsection{Reflections on human relationships with urban species}

But what of this void in urban species, why does it matter? Rosemary-Claire Collard \& Jessica Dempsey's 'Capitalist Natures in Five Orientations' (2017) positions species in relation to their value in a capitalist economy, examining emotions around certain animals and how these emotions relate to what they produce societally. Under this framework, urban foraging species represent outcast surplus species to the system, catching a free resource ride with humans- at worst, they are positioned as an active threat to human sanitation and property. They can function as havens for transmissible pathogens, and incur homeowner fines. Urban species operate outside the function of capital, and so their value has not been recognized outside of the tether they provide to nature for urban residents, as the pigeon paradigm proposes. If we postulate, under that paradigm, that one of the innate values these urban species provide is as an 
opportunity for urban dwellers to experience nature, shouldn't urban species be protected as such?

Tying in to the German Animal Welfare Association's statements warning that their city's pigeon-population was at risk of starvation because of its strict loyalty to the now-vacant downtown area, we can assume that there was potential for similar starvation in Portland pigeons. With reference to the previous media analysis, utilizing surplus and threat models, there seems to exist a spectrum of malign in the public opinion that resulted in rats receiving more backlash than squirrels. As squirrels were the most commonly observed species in the humandominated parks, frequent interaction with squirrels may have desensitized urban humans to their presence, in a way that had not been the case for rats-until the COVID-19 pandemic.

In this work I suggest it would be valuable to better understand nonhuman urban species. Of course, the importance of managing urban species in regards to disease transmission doesn't go unacknowledged, in consideration to the pandemic which first initiated these food waste changes. But perhaps urban green spaces can provide, in the post pandemic world, dynamic areas of species variation, and exert a downwards pressure on forager populations independent of food waste. With a lack of concrete data on urban species living in asphalt-lined, inner-city environments, our knowledge of urban foragers and their lives on the campus their share with students traverses remains incomplete. The months post-pandemic could present a unique opportunity for camera-trap installation near edible food repositories such as dumpsters. The fragmented micro-system that composes urban campuses creates a unique stage to witness the theatre of urban foragers and their food sources. As noted in 'Pests in the City: Flies, Bedbugs, Cockroaches, and Rats' (D. Biehler, 2013) the history of humans and our whiskered/ beaked 
neighbors has been fraught with both conflict and cohabitation. Many non-human species flourish and interact in urban areas: for example, urban raptors are becoming a reality in both cities and suburbs (Bednarz, 2019) and it is not uncommon nowadays to see a Red-Tailed Hawk pursued by a flock of crows through high-rises, and owls have moved into suburban attics and garages as predators of rodents like squirrels.

The park blocks, landscaped jointly by both PSU and the city of Portland, provide a unique greenspace opportunity that could better accommodate the needs of non-human species. If restructured, perhaps open grassy knolls and neat bushes could exist alongside denser vegetation for larger raptors to make their homes. Portland itself stands as an example of thoughtful and collaborative wildlife management- for example, the dedicated shift of the downtown crow roost population from the Transit Mall to the Park Blocks through hawk hazing was seen to eliminate many complaints from businesses on droppings. This less-aggressive management strategy shows how teamwork between the City of Portland, the Portland Audubon Society, and the organization Downtown Clean and Safe were able to study and mitigate urban foragers. However, this also is an example of species not only using the Park Blocks as a greenspace refuge, but also of the pragmatic intersection urban wildlife finds itself in, snug between city and capital. This example highlights the importance of managing urban species holistically, instead of traditionally, as a nuisance. In terms of food waste, this issue is more nuanced. Food waste is often monetarily accounted for through supply chain studies. In relation to the pandemic, many studies have tried to quantify the amount of food lost from both farms and businesses, and estimate the economic toll the pandemic has taken. Urban foraging species however, compose a vital string in the urban web, and are often so close to us humans that we become myopic. 
Symptomatic of this is a lack of data in terms of supply chain management. Urban trash systems are studied without consideration for the eventual urban foragers who will cycle some of this edible waste into the city ecosystem.

More changes for urban species in Portland are being heralded in the near future: While the current Metro food scraps collection program is voluntary, dumping food in garbage bins will be discouraged for restaurants, and scrap collection will become mandatory for certain businesses as early as March 2022. This might spell future changes in urban foraging behavior, and changing population density of species in the city. Portland has historically been able to manage its rat population with careful bin management, but as the urban core continues to expand, both classically anthropophilic and more 'rural' species will have to contend with human infringement. Fragmented inter-urban greenspaces and the small urban foragers who thrive in them are often discounted in manner or method of study. Perhaps as humans, we are biased toward the study of 'charismatic megafauna' and larger mammals, rather than seeing the wealth of life in our own backyards, apartment courtyards with a few topiaries, patches of dandelions and sparse trees behind an alleyway dumpster, or the mossy carpet beside a bench, where squirrels are inevitably fed bread slices by an older woman every weekend. Measuring the activities of urban species has a great deal to tell us about urban metabolism, especially during the fluctuations of urban life, and as we decide which urban spaces are worth studying. Moreover, there is a need for research into how we could improve our urban greenspaces to accommodate a more diverse assortment of life.

Urban non-human species are not the most exotic, and they have been living alongside us so long that perhaps the pigeons and rats have become more synonymous with the subway than nature. 
But perhaps by coming to better understand the animals with which we share cities, we can come to better understand ourselves.

Acknowledgements

I would like to extend my deepest thanks to my advisor Alida Cantor for her tireless support, to my professor Jennifer Peterson, and Olyssa Starry and Hunter Storm of UWIN for collaborating and providing me with not only hard-raught data during a pandemic, but also kindness, suggestions and advice.

\section{References}

Adamshick, Dave. "Waste Not, Want Not.” Portland Farmers Market, 22 Feb. 2021, www.portlandfarmersmarket.org/waste-not-want-not/.

Biehler, Dawn, (2013). Pests in the City: Flies, Bedbugs, Cockroaches, and Rats. Seattle: University of Washington Press.

Clergeau P., Mennechez G., Sauvage A., Lemoine A. (2001) Human perception and appreciation of birds: A motivation for wildlife conservation in urban environments of France. In: Marzluff J.M., Bowman R., Donnelly R. (eds) Avian Ecology and Conservation in an Urbanizing World. Springer, Boston, MA.

Davies, R. G., Webber, L. M., \& Barnes, G. S. (2004). Urban wildlife management-it's as much about people. Urban Wildlife: More Than Meets the Eye'.(Eds D. Lunney, and S. Burgin.) pp, 38-43

Dunn, R.R., Gavin, M.C., Sanchez, M.C. and Solomon, J.N. (2006), The Pigeon Paradox: Dependence of Global Conservation on Urban Nature. Conservation Biology, 20: 18141816.

Ethan H. Decker, Scott Elliott, Felisa A. Smith, Donald R. Blake, and F. Sherwood Rowland (2000) Energy and Material Flow Through the Urban Ecosystem, Annual Review of Energy and the Environment 2000 25:1, 685-740

Ellison, B. and M. Kalaitzandonakes (2020) "Food Waste and Covid-19: Impacts along the Supply Chain." farmdoc daily (10):164, Department of Agricultural and Consumer Economics, University of Illinois at Urbana-Champaign, September 10, 2020. 
Faeth, Stanley \& Warren, Paige \& Shochat, Eyal \& Marussich, Wendy. (2005). Trophic Dynamics in Urban Communities. Bioscience. 55. 399-407.

Gilbert, F. (1982). Public Attitudes toward Urban Wildlife: A Pilot Study in Guelph, Ontario. Wildlife Society Bulletin (1973-2006), 10(3), 245-253.

Gibbs, James \& Buff, Matthew \& Cosentino, Bradley. (2019). The Biological System-Urban Wildlife, Adaptation, and Evolution: Urbanization as a Driver of Contemporary Evolution in Gray Squirrels (Sciurus carolinensis). 10.1007/978-3-030-11259-2_12.

Hill, KJ (2018) "Rock Pigeons of Portland, Oregon: 10 Year Management Plan." Capstone.paulsmiths.edu, Paul Smith's College, capstone.paulsmiths.edu/system/files/videos/Hill_2018.05.03.pdf.

Jerolmack, C. (2008). How Pigeons Became Rats: The Cultural-Spatial Logic of Problem Animals. Social Problems, 55(1), 72-94. doi:10.1525/sp.2008.55.1.72

Jribi, S., Ben Ismail, H., Doggui, D. et al. (2020) COVID-19 virus outbreak lockdown: What impacts on household food wastage?. Environ Dev Sustain 22, 39393955ResKitchenDiarySurvey.pdf (oregon.gov)

Karr, Merilee. "In Portland, Even Our Rats Are Special." Portland Monthly, Portland Monthly 28 Oct. 2016, www.pdxmonthly.com/news-and-city-life/2014/05/rouhs-rodentsof-unusual-health-may-2014.

Lepczyk, Chris (2018) Urban Ecology: where the wild meets the city. PLOS Collections

Ma, Michelle (7 Apr. 2015) "Common Birds Bring Economic Vitality to Cities, New Study Finds." UW News, University of Washington, 7 Apr. 2015,

Newsome, Thomas M.; Van Eeden, Lily M. 2017. "The Effects of Food Waste on Wildlife and Humans" Sustainability 9, no. 7: 1269. https://doi.org/10.3390/su9071269

Nik,Martin. "Pigeons at Risk of Starvation over Coronavirus Empty Streets." DW.COM, 31 Mar. 2020, www.dw.com/en/pigeons-at-risk-of-starvation-over-coronavirus-emptystreets/a-52965011.

O'Connor, Kathleen E., "An analysis of the parasite communities of New York gray squirrels (Sciurus carolinensis) and Eastern chipmunks (Tamias striatus)" (2010). Honors Theses. 1201. https://digitalworks.union.edu/theses/1201

Partecke, Jesko \& Gwinner, Eberhard. (2007). Increased sedentariness in European Blackbirds following urbanization: A consequence of local adaptation?. Ecology. 88. 882-90. 10.1890/06-1105. 
Poe, Melissa r, Joyce LeCompte, Rebecca McLain \& Patrick Hurley (2014) Urban foragin and the relational ecologies of belonging, Social \& Cultural Geography, 15:8, 901-919, DOI: $10.1080 / 14649365.2014 .908232$

Roe, B.E., Bender, K. and Qi, D. (2021), The Impact of COVID-19 on Consumer Food Waste. Appl Econ Perspect Policy, 43: 401-411. https://doi.org/10.1002/aepp.13079

Rosemary-Claire Collard \& Jessica Dempsey (2017) Capitalist Natures in Five Orientations, Capitalism Nature Socialism, 28:1, 78-97,

Rutz, C., Loretto, MC., Bates, A.E. et al. COVID-19 lockdown allows researchers to quantify the effects of human activity on wildlife. Nat Ecol Evol 4, 1156-1159 (2020). https://doi.org/10.1038/s41559-020-1237-z

Sallinger, Bob. "The Downtown Portland Crow Roost." Portland Audubon, The Audubon Society, 10 Mar. 2020, audubonportland.org

Spritzer, Pam. "Perspective | How a Sickly Squirrel Offered Me Unexpected Comfort." The Washington Post, WP Company, 7 Feb. 2021, www.washingtonpost.com/lifestyle/2021/02/08/squirrel-comfort-covid-loss/.

Sallinger, Bob. "Portland Audubon Backyard BioBlitz." Portland Audubon, The Audubon Society, 21 July 2020, audubonportland.org/our-work/protect/habitat-andwildlife/urban/portland-audubon-backyard-bioblitz/.

Schoonenboom, J., \& Johnson, R. B. (2017). How to Construct a Mixed Methods Research Design. Kolner Zeitschrift fur Soziologie und Sozialpsychologie, 69(Suppl 2), 107-131.

Yin, D., Gao, Q., Zhu, H., \& Li, J. (2020). Public perception of urban companion animals during the COVID-19 outbreak in China. Health \& place, 65, 102399. https://doi.org/10.1016/j.healthplace.2020.102399

Zhang, Sarah (2020) "Rats Have Not Change. We Have." The Atlantic, Atlantic Media Company, 8th of June, 2020, www.theatlantic.com 